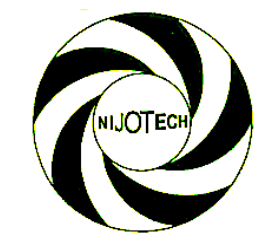

Nigerian Journal of Technology (NIJOTECH)

Vol. 39, No. 3, July 2020, pp. 721 - 731

Copyright@ Faculty of Engineering, University of Nigeria, Nsukka,

Print ISSN: 0331-8443, Electronic ISSN: 2467-8821 www.nijotech.com

http://dx.doi.org/10.4314/nit.v39i3.10

\title{
OIL PALM EMPTY FRUIT BUNCH ASH STABILIZED LATERITE AS A FILL MATERIAL FOR LOW-VOLUME PAVEMENT
}

\author{
J. A. Oke ${ }^{1, *}$, N. O. Obaji ${ }^{2}$ and K. J. Osinubi ${ }^{3}$ \\ 1,2, DePT OF CiVIL \& ENVIRONMENTAL ENGINEERING, UNIVERSITY OF LAGOS, AKOKA, LAGOS STATE, NIGERIA. \\ 3, Department of Civil Engineering, AhmAdu Bello University, Zaria 810001, KAduna State, NIGERIA \\ E-mail addresses; ${ }^{1}$ idaraobong2013@gmail.com, ${ }^{2}$ nobaji@unilag.edu.ng, ${ }^{3}$ kosinubi@yahoo.com
}

\begin{abstract}
A reddish-brown laterite was treated with up to $14 \%$ oil palm empty fruit bunch ash (EFBA) by dry weight of soil and compacted with the British Standard light, BSL (or Standard Proctor) compactive effort. Index, compaction, strength and durability tests as well as microanalysis of the natural and stabilized specimens were carried out. The index, compaction characteristics (maximum dry density, MDD and optimum moisture content, OMC) and strength properties (California bearing ratio, CBR and unconfined compressive strength, UCS) were improved with higher EFBA treatment. Peak un-soaked and soaked CBR values of 70.0 and $45.0 \%$, as well as peak UCS strengths of 253.0, 462.0 and $577 \mathrm{kN} / \mathrm{m}^{2}$ at 7, 14 and 28 days curing were recorded at $8 \%$ EFBA content. Based on the CBR specification specified in the Nigerian General Specifications, the laterite optimally treated with $8 \%$ EFBA compacted with the BSL compactive effort can be used as a fill material in the construction of low-volume traffic pavement. The benefit of the EFBA application is primarily the reduction of the adverse environmental impact of the oil palm empty fruit bunch waste.
\end{abstract}

Keywords: California bearing ratio, durability, laterite, oil palm empty fruit bunch ash, microanalysis, stabilization

\section{INTRODUCTION}

The very poor state of roads in Nigeria calls for great concern. In order to meet up with the enormous demand for durable roads, cheaper means of building them are essential [1] however, the ability to keep the cost of road construction to a manageable limit depends on the quantity of the materials that can be sourced locally. In the humid tropical regions, including Nigeria, laterite soil is the major local road construction material. This laterite soil which is formed through the process of laterization can on its own, serve as sub-base and/or base course material for road structures but there are however situations where these soils may contain substantial amounts of silica in the form of clay silicate minerals which most times affect its strength and stability as a construction material [2]. Earlier researches that were carried out on the use of laterite soil in pavement construction showed that the soil lacked the required engineering properties to provide the necessary strength for constructing durable pavements hence the need to carry out stabilization with the aim of improving its properties to meet the desired strength and stability especially in areas where deposits of these types of laterite exist and sourcing for alternative soils which would be better suitable are too expensive [3-6].

The over dependence on the utilization of industrially manufactured soil improving additives (e.g., cement, lime and bitumen), have kept the cost of construction of stabilized roads high $[7,8]$. This hitherto, has continued to deter the underdeveloped and poor nations of the world from providing accessible roads to their rural dwellers that constitute the higher percentage of the population and are mostly agriculture dependent [7] and so, in order to improve on the engineering properties of laterite soils used for pavement construction in a cost-effective manner, studies were carried out on the ashes obtained from the burning of agricultural by-products for use as potential stabilizers. 


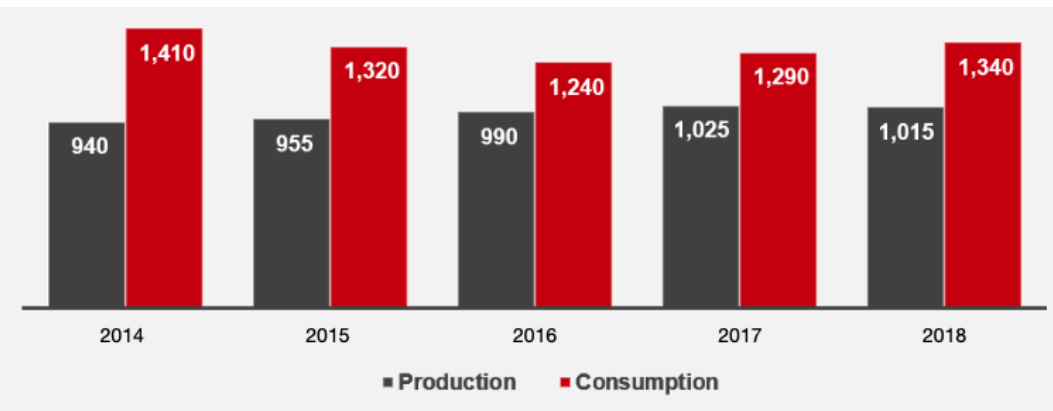

Figure 1: Palm oil production vs consumption in Nigeria ('OOOMT) 2018. Source: World Bank, PwC analysis.

The ashes obtained from the burning of wastes such as rice husk [9], cassava peel $[10,11]$, sugar cane [12, 13] and coconut shell husk [7] were studied and results showed that the use of these ashes as alternatives to the conventional stabilizers (e.g., cement, lime and bitumen) were beneficial for improving weak soil in a cost-effective way $[12,13]$.

Studies has shown that about $43-45 \%$ of mill residues (i.e., empty fruit bunch; EFB, shell and fiber) are generated from harvested oil palm fruits during the process of producing palm oil [14]. In Nigeria, about 1.02 million metric tonne of palm oil was produced in $2018[15,16]$; this implies that about 459,000 metric tonne of waste was generated during the production of palm oil in 2018.

The data provided indicates that the disposal of about 459,000 metric tons of wastes from palm oil mills might have adverse environmental impact if not adequately managed hence this study was aimed at evaluating oil palm empty fruit bunch waste ash as a potential stabilizer to laterite soil for the purpose of constructing low volume roads.

\subsection{Low volume roads}

Low volume roads have been defined as roads that carry less than 1.0 million equivalent standard axles (mESA) over their design life of typically 15 years [17, 18]. The annual average daily traffic (AADT) of such roads is usually less than 300 motorized vehicles per day (VPD). Sometimes, the VPD could exceed 300 however, for as long as the $1.0 \mathrm{mESA}$ limit is not exceeded, the road can still be referred to as a low volume road. In recent times, the design and construction of low volume roads is beginning to receive high priority as a result of the increasing awareness that the accessibility of rural communities is vital for their sustained socio-economic development $[7,18]$.

\section{MATERIALS AND METHODS \\ 2.1 Materials}

2.1.1 Soil: The laterite sample used in this study was obtained from a borrow pit located along Itokin Road (Latitude $6^{\circ} 60^{\prime} 0^{\prime \prime} \mathrm{N}$ and Longitude $3^{\circ} 50^{\prime} 0^{\prime \prime} \mathrm{E}$ ), Adamo, Ikorodu North Local Government Area in Lagos state at a depth of about $1.5-2.5 \mathrm{~m}$ below the existing ground level in order to minimize the organic topsoil using the method of disturbed sampling.

\subsubsection{Oil Palm Empty Fruit Bunch Ash (EFBA):}

The oil palm empty fruit bunch (EFB) used in this study was collected from a local milling factory in Atan (Latitude $6^{\circ} 46^{\prime} 0^{\prime \prime} \mathrm{N}$ and Longitude $2^{\circ} 48^{\prime} 0^{\prime \prime} \mathrm{E}$ ), Ijebu North East Local Government Area in Ogun state. The oil palm empty fruit bunch (EFB) was sun-dried to get it as close as possible to a very dry state for the ease of open-air burning (see Figure 2a).

The cooled ash was passed through a $0.075 \mathrm{~mm}$ aperture sieve size (see Figure $2 \mathrm{~b}$ ) and stored in airtight containers to avoid pre-hydration. Chemical analysis using atomic absorption spectrophotometer (AAS) and direct reading spectrophotometer were carried out to determine the oxide contents in the ash (see Table 2).

\subsection{Methods}

\subsubsection{Index properties}

Tests to determine the index properties (natural moisture content, liquid limit; $L L$, plastic limit; $P L$, plasticity index; PI, linear shrinkage; LS and specific gravity; SG) of the laterite soil were carried out in accordance with the procedures outlined in BS codes $[19,20]$.

\subsubsection{Compaction}

Compaction test was carried out to obtain the relationship between dry density and moisture content of the laterite soil. 


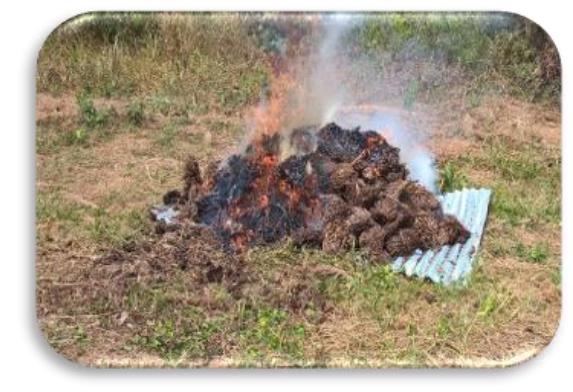

Figure 2a: Open air burning of EFB

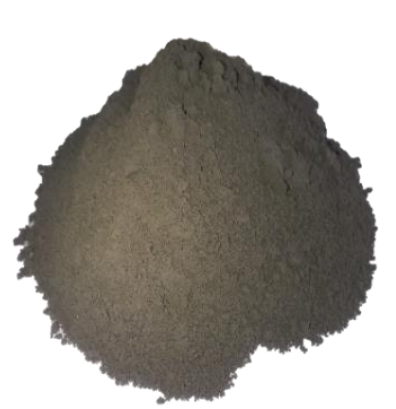

Figure 2b: Ash obtained
The BSL compactive effort, which is easily achieved on the field, was used to compact the laterite treated with EFBA in stepped concentration of $2 \%$, up to maximum of $14 \%$ by dry weight of soil as outlined in BS codes $[19,20]$. The soil samples were compacted in a mould having a volume of $1000 \mathrm{~cm}^{3}$ in 3 layers, each layer receiving 27 blows from a $2.5 \mathrm{~kg}$ rammer falling through a height of $300 \mathrm{~mm}$. The blows were uniformly distributed over the surface of each layer. After the compaction was completed, the collar was removed and the sample at the top was leveled off with a straight edge. The mould and the compacted sample were then weighed to the nearest $1 \mathrm{~g}, \mathrm{~m}^{2}$.

\subsubsection{Strength}

Strength tests (i.e., unconfined compression strength; UCS and California bearing ratio, CBR) were carried out on the natural and EFBA treated soils and the specimens were prepared at their respective optimum moisture contents (OMCs). For the UCS samples, the compacted samples were extruded from the mould using a cylindrical steel measuring $76 \mathrm{~mm}$ by $38 \mathrm{~mm}$ diameter. The natural and treated specimens were cured for 7,14 and 28 days respectively and after the curing periods had elapsed, the specimens were placed centrally on the lower platen of a compression-testing machine and the compressive force was applied to the specimens with a strain control at $0.10 \% \mathrm{~mm}$. Record was taken simultaneously of the axial deformation and the axial force at regular intervals until failure of the sample occurred. Three specimens were used for each test and the average result was taken. The UCS was determined at the point on the stress-strain curve at which failure occurred. The tests were also carried out in accordance with BS codes [19,20].

For the CBR test, $5.0 \mathrm{~kg}$ of the natural / oil palm EFBA treated laterite samples were prepared at their respective OMCs in moulds having a volume of 2360 $\mathrm{cm}^{3}$ and compacted using the BSL Compactive effort.

Nigerian Journal of Technology,
The compaction was in three layers, each layer receiving 62 blows from a $2.5 \mathrm{~kg}$ rammer. After compacting, the base plates were removed, and the compacted specimens were placed in sealed polythene bags for seven days and then tested on the eighth day while the soaked compacted samples were placed in sealed polythene bags for six days and thereafter soaked for 24 hours before testing. For the testing procedure, the base plates were replaced, and the specimens transferred to the CBR testing machine and positioned on the lower plate of the machine. The plunger was then made to penetrate the specimen at a rate $1.3 \mathrm{~mm} / \mathrm{min}$ until the specimen failed. The mould was then inverted, base plate removed and the procedure repeated for the base of the specimens. The CBR value was calculated at penetrations of 2.5 and $5.0 \mathrm{~mm}$ each for top and bottom; the greater of the two and provided their difference was within 10 $\%$ of one another, the greater value was taken as the CBR value of the sample [21].

\subsubsection{Durability}

A standard engineering test for evaluating the potential degradation characteristic of stabilized laterite is needed in order to establish means of evaluating the long-term durability of the materials in a road section. The durability assessment (under adverse field conditions) of the soil sample was determined by resistance to loss in strength when immersed in water. It is expressed as the ratio of UCS specimens wax-cured for 7 days and soaked (dewaxed top and bottom) for another 7 days to the UCS specimens wax-cured for 14 days.

\subsubsection{Microanalysis}

Scanning Electron Microscope (SEM) and Energy Dispersive X-Ray Spectrometer (EDS) were used to analyze both the natural and optimally treated samples wax-cured for 7 and 28 days and left to airdry for 120 days respectively. The results obtained

Vol. 39, No. 3, July 2020 
were compared to results in previous researches where the samples were wax cured for 7 and 28 days and tested immediately after de-waxing without airdrying. The comparison was to ascertain if there would be changes in the morphology of the samples de-waxed and air-dried for 120 days before testing compared to those tested immediately after dewaxing.

The samples were prepared using the BSL compactive effort, and scanned after 120 days using the JSM-7600F microscope as loose particles coated with Iridium on a sticky double-sided carbon tape. The Iridium was used to coat the particles in order to minimize electrostatic charging effects during the electron imaging thereafter, magnification was carried out at $x 10,000$. The elemental analysis at different zones (spectra) of the scanned sample were done by the EDS in form of a plot with the energy in kiloelectronvolt (keV) on the abscissa and the intensity in counting phantons per electron volt (cps/eV) on the ordinate.

\section{DISCUSSION OF RESULTS}

\subsection{Properties of the materials used in the study}

\subsubsection{Laterite}

Laterite is the most common material used for pavement construction due to its abundance in Nigeria. However, findings of previous researches [4, $5,6]$ have shown that the material lacks the required engineering properties to provide the necessary strength for durable roads hence the need for its improvement. The index properties as well as the particle size distribution of the natural laterite are shown in Table 1 and Figure 3.

\subsubsection{Empty fruit bunch ash}

The detected oxide composition of oil palm empty fruit bunch ash is summarized in Table 2. The combined composition of $\mathrm{SiO}_{2}, \mathrm{Al}_{2} \mathrm{O}_{3}$ and $\mathrm{Fe}_{2} \mathrm{O}_{3}$, in the EFBA used for this study did not satisfy the minimum value of $70 \%$ specified for pozzolans [22]. However, the ash has relatively high $\mathrm{CaO}$ content of $52.2 \%$, which was responsible for the strength gain recorded in the results obtained.

\subsection{Index properties}

The variation in the index properties of laterite with EFBA content is shown in Figure 4. Generally, the values of the index properties decreased with higher EFBA content. The values decreased from 47.0 to
$34.0 \%, 24.0$ to $22.0 \%$ and 23.0 to $12 \%$ at $8 \%$ EFBA content for $\mathrm{LL}, \mathrm{PL}$, and $\mathrm{PI}$ respectively. The same trend was recorded in values of $\mathrm{LS}$ and SG where the values at $8 \%$ EFBA were recorded at $3.9 \%$ and $2.2 \%$ respectively. The general reduction may be due to cation exchange reaction that liberated absorbed water molecules at the outer layers of the soil leading to the flocculation and aggregation of the soil [23, 24]. The reduction could also be attributed to the effect of the $\mathrm{Ca}^{2+}$ in the EFBA on the high affinity for $\mathrm{Si} / \mathrm{Al}$ of the clay and silt fractions of the soil as well as the agglomeration and flocculation of the clay particles which resulted in the exchange of ions at the surface of the clay particles $[25,26]$. The reduction in SG could be attributed to lower combined specific gravity of EFBA (2.31) replacing the laterite soil particles with higher specific gravity (2.62). This observation is in agreement with the findings reported by other researchers $[27,28]$. The $L L$ of $34 \%$ and PI of $12 \%$ at an optimum blend of $8 \%$ EFBA content meets with the requirement specified for fill material which is given as LL: $0-45 \%$ and PI: $0-20 \%$ [21].

\subsection{Compaction characteristics}

3.3.1 Maximum dry density. The variation of maximum dry density (MDD) of laterite with EFBA content is shown in Figure 5 . There was a sharp decrease from 1.60 to $1.54 \mathrm{Mg} / \mathrm{m}^{3}$ at $2 \%$ EFBA content thereafter, a further increase in the EFBA content resulted in a general decrease in MDD at a decreasing manner to a value of $1.55 \mathrm{Mg} / \mathrm{m}^{3}$ at $8 \%$ EFBA content. The sharp decrease in MDD with addition of EFBA is a general indication of soil improvement [12]. It may be due to cation exchange reactions and may also be due to the EFBA occupying the voids within the soil matrix and in addition, the flocculation and agglomeration of the clay particle due to exchange of ions [29]. The general decrease observed with increasing EFBA content could be due to the fact that for any soil/admixture, there is always a water content that produces maximum strength [30-34].

\subsubsection{Optimum moisture content}

The variation of optimum moisture content (OMC) of laterite with empty fruit bunch ash content is shown in Figure 6. It was observed that there was an increase in OMC with the increased EFBA content. The OMC increased from $18.5 \%$ for the natural soil to $22.3 \%$ at $8 \%$ EFBA content. The observed 
increase in OMC with increased EFBA content is in agreement with the findings $[24,30,35,36]$. The treatment of laterite with EFBA resulted in the reduction of the clay and silt fractions but enhanced the formation of transitional pseudo-coarse fraction with large surface areas that required more water for adequate compaction of the laterite - EFBA mixtures $[24,32-34,37,38]$.

Table 1: Engineering properties of the natural

\begin{tabular}{ll}
\multicolumn{2}{c}{ laterite } \\
\hline Property & Quantity \\
\hline Natural Moisture Content, \% & 23.4 \\
Percentage Passing No. 200 sieve (75 & 68.2
\end{tabular}

\begin{tabular}{ll}
\hline Property & Quantity \\
\hline Liquid Limit, \% & 47.0 \\
Plastic Limit, \% & 24.0 \\
Plasticity Index, \% & 23.0 \\
Linear Shrinkage, \% & 9.4 \\
Specific Gravity & 2.62 \\
AASHTO Classification & $\mathrm{A}-7-6(15)$ \\
USCS & $\mathrm{CL}$ \\
Maximum Dry Density, Mg/m ${ }^{3}$ & 1.6 \\
Optimum Moisture Content, \% & 18.5 \\
Unconfined Compressive Strength (7 & 161.0 \\
days curing), kN/m² & \\
California bearing ratio (24 hrs & 11.0 \\
soaking), \% & \\
Colour & Reddish brown \\
\hline
\end{tabular}
$\mu \mathrm{m}$ aperture)

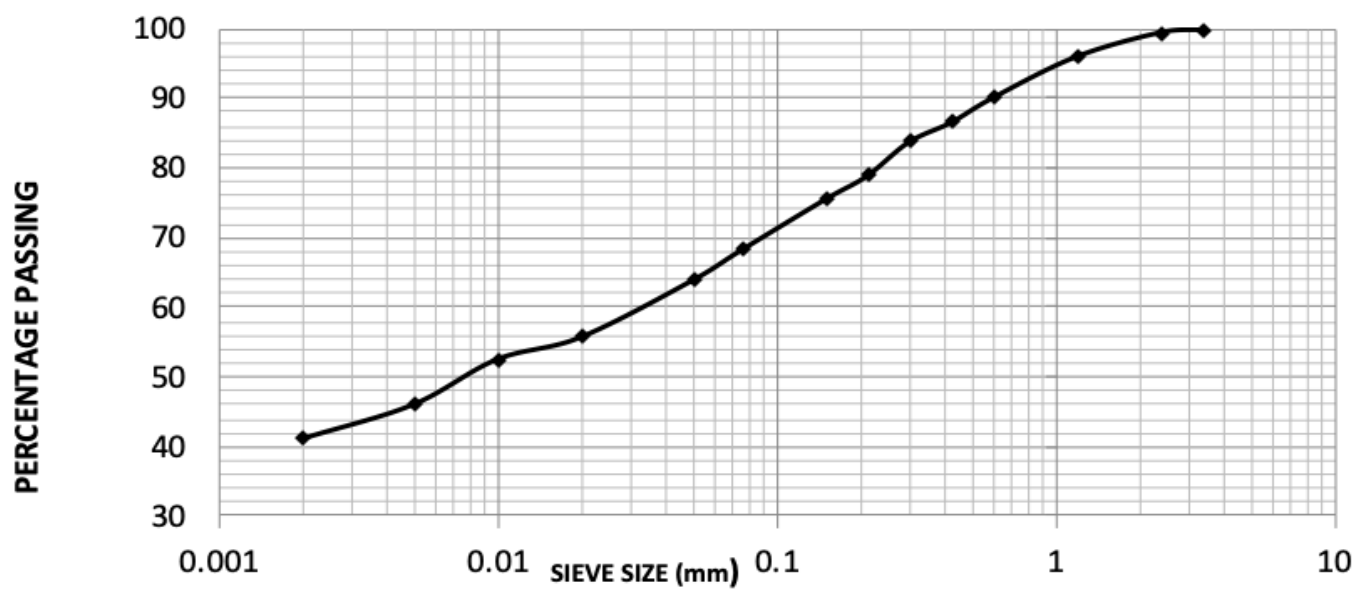

Figure 3: Particle size distribution of the natural laterite.

Table 2: Detected oxide composition of EFBA

\begin{tabular}{lllllllll}
\hline Oxide & $\mathrm{SiO}_{2}$ & $\mathrm{Al}_{2} \mathrm{O}_{3}$ & $\mathrm{Fe}_{2} \mathrm{O}_{3}$ & $\mathrm{~K} 2 \mathrm{O}$ & $\mathrm{CaO}$ & $\mathrm{MgO}$ & $\mathrm{Na}_{2} \mathrm{O}$ & LOI \\
\hline Conc. \% & 0.05 & 0.003 & 0.007 & 1.24 & 52.15 & 11.10 & 2.72 & 0.001 \\
\hline
\end{tabular}

LOI: Loss on Ignition

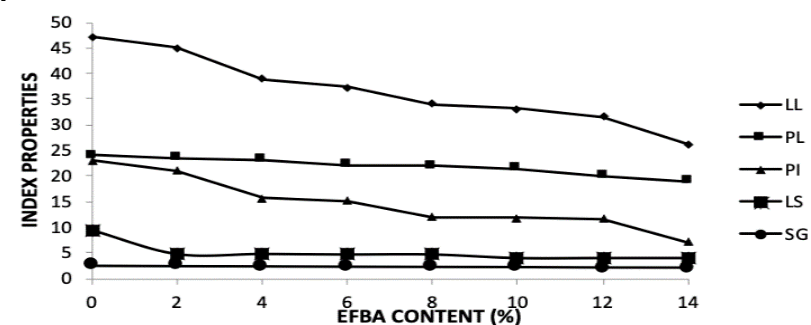

Figure 4: Index properties of EFBA treated soil

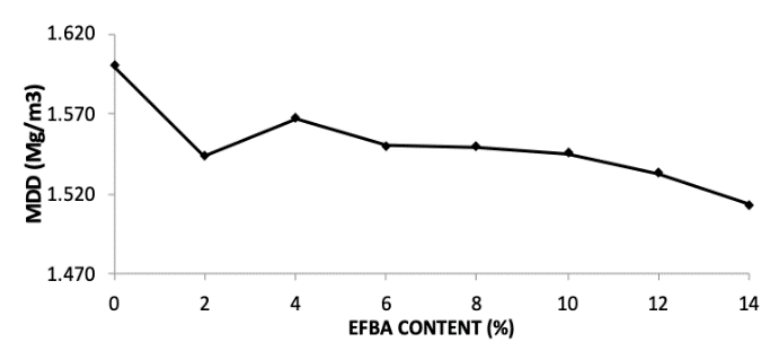

Figure 5: Variation of maximum dry density $(M D D)$ of laterite with empty fruit bunch ash (EFBA) content

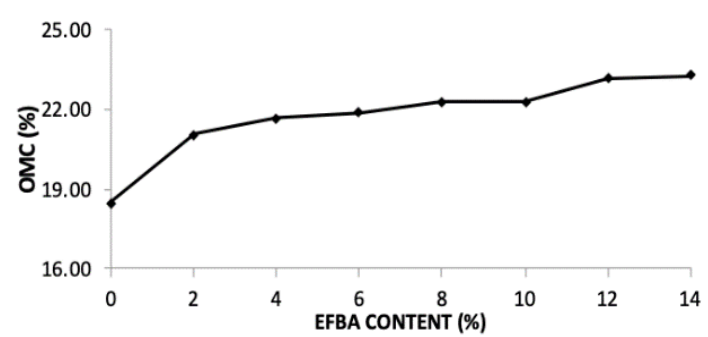

Figure 6: Variation of optimum moisture content (OMC) of laterite with empty fruit bunch ash (EFBA) content

\subsection{Strength Characteristics}

\subsubsection{Unconfined compressive strength}

The variation of unconfined compressive strength (UCS) of laterite soil with EFBA content is shown in Figure 7. The UCS values for 7, 14- and 28-days curing period initially increased from values of 161.0, 194.0 and $210.0 \mathrm{kN} / \mathrm{m}^{2}$ for the natural laterite to 
peak values of 253.0, 462.0 and $577.0 \mathrm{kN} / \mathrm{m}^{2}$ respectively, at $8 \%$ EFBA content and thereafter decreased to $228.0,381.0$ and $408.0 \mathrm{kN} / \mathrm{m}^{2}$ at $14 \%$ EFBA content. The results obtained show that specimens treated with BSL Compactive effort did not meet the 7-day $1710 \mathrm{kN} / \mathrm{m} 2$ specified by [39] as criterion for adequate Cement stabilization, however, the stabilized material can be used as a fill material.

The initial increase in UCS values could be attributed to ion exchange at the surface of the clay particles. The $\mathrm{Ca}^{2+}$ in the additives reacted with the lower valence metallic ions in the clay microstructure, which resulted in flocculation and agglomeration of the clay particles $[32-33,40]$. The increase in the UCS values was primarily due to the formation of various compounds such as calcium silicates hydrates (CSH), calcium aluminate hydrates (CAH) and micro fabric changes, which were responsible for strength development [32, 39, 41-43].

\subsubsection{California bearing ratio}

The variation of un-soaked and soaked CBR of laterite treated with EFBA content is shown in Figure 8. The un-soaked CBR value increased steadily from $15.0 \%$ for the natural laterite to a peak value of $70.0 \%$ at $8 \%$ EFBA content and then decreased to $40.0 \%$ at $14 \%$ EFBA content. This initial increase in the CBR value could be as a result of the presence of adequate amounts of calcium required for the formation of calcium silicate hydrate (CSH) and calcium aluminate hydrate (CAH), which are the major compounds responsible for strength gain [11].
For the soaked condition, a peak CBR value of 45.0 $\%$ was recorded at $8 \%$ EFBA content. The lower values recorded in comparison to the un-soaked CBR values were due to ingress of water into the specimen, which led to a reduction in strength of the sample. It was also observed that though the CBR values of the soaked samples decreased compared to the un-soaked samples, the requirement for fill material was still satisfied at $8 \%$ EFBA content [20].

\subsection{Durability}

Durability assessment of soil samples involves the simulation of some of the worst conditions that could be experienced in the field. In this research, durability was evaluated by the immersion of specimens in water to determine the resistance to loss in strength, which is more appropriate for tropical regions like Nigeria [44-46]. Conventionally, an allowable $20 \%$ loss in strength (that is $80 \%$ resistance to loss in strength) is recommended for a specimen cured for 7 days and immersed in water for 4 days [24, 44-47].

The variation of resistance to loss in strength of laterite treated with EFBA content is shown in Figure 9. Resistance to loss in strength value marginally increased from $17.4 \%$ for the natural soil to a peak value of $19.3 \%$ at $8 \%$ EFBA content and thereafter decreased to $13.2 \%$ at $14 \%$ EFBA content. The durability results did not however meet up with recommendations probably because the specimens were tested under condition when immersed in water for 7 days and not the recommended 4 days [44].

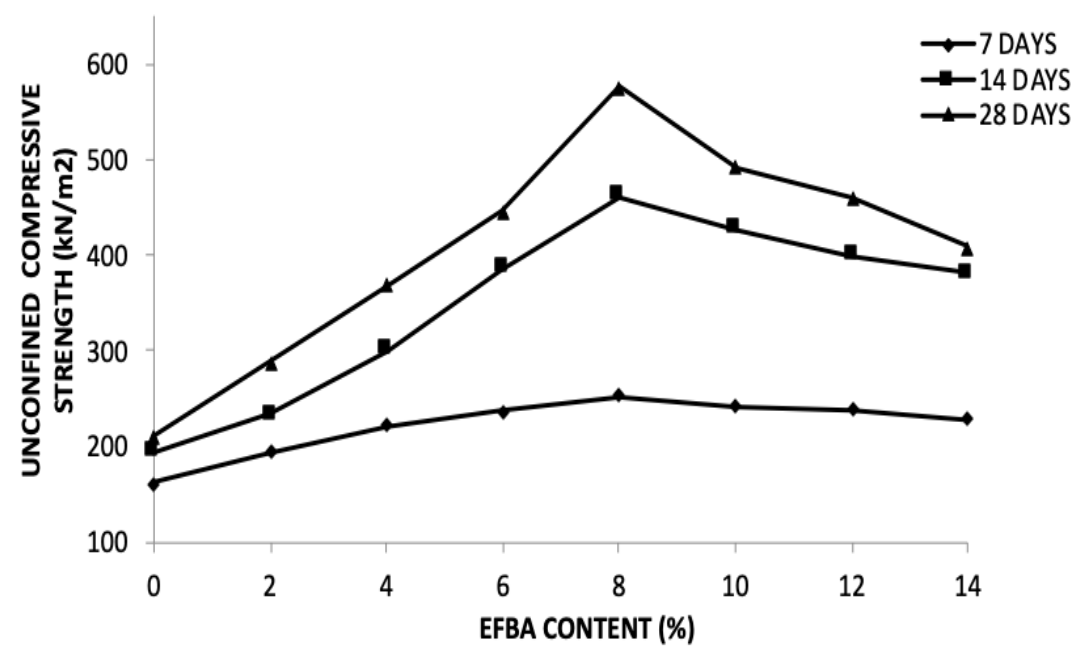

Figure 7: Variation of unconfined compressive strength (7, 14 and 28 days curing period) of laterite with empty fruit bunch ash (EFBA) content 


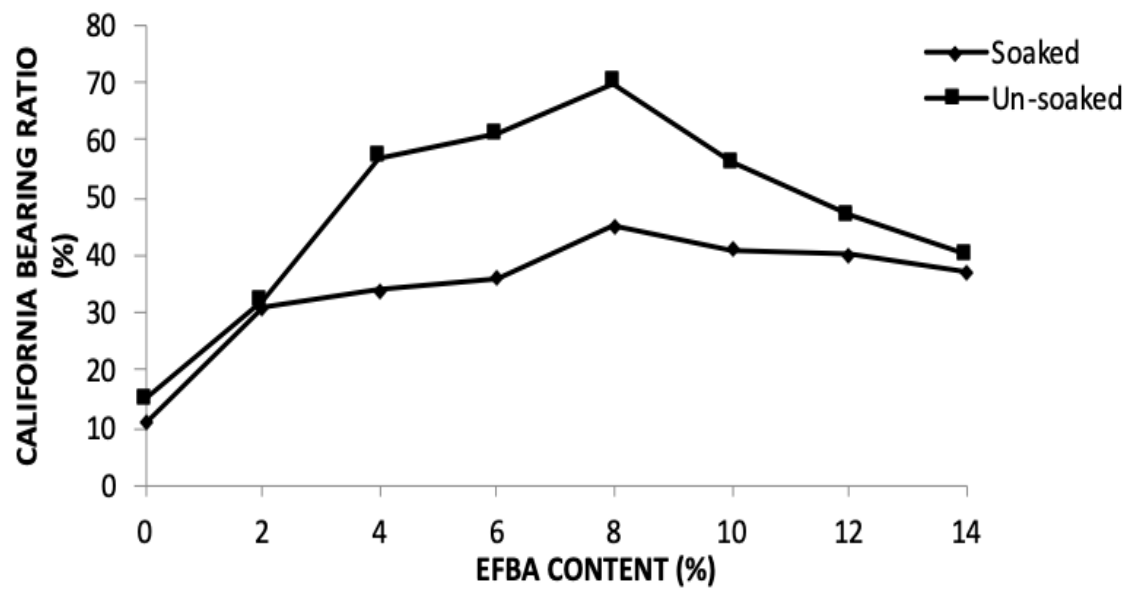

Figure 8: Variation of California bearing ratio (un-soaked and soaked conditions) of laterite with empty fruit bunch ash (EFBA) content

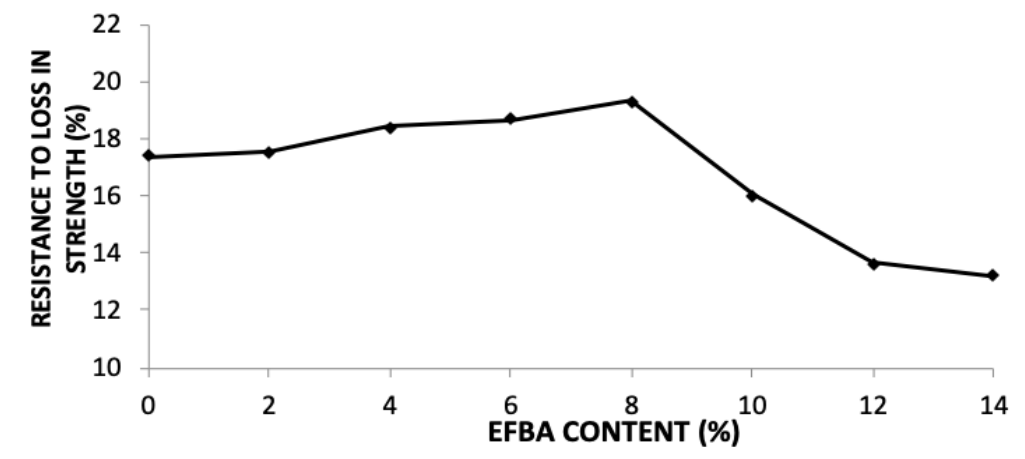

Figure 9: Variation of resistance to loss in strength of laterite with empty fruit bunch ash (EFBA) content.

\subsection{Microanalysis}

\subsubsection{Micrograph and spectroscopy of specimen wax - cured for 7days and air-dried for 120 days}

The scanning electron micrographs of the natural and optimally treated samples wax-cured for 7 days and air-dried for 120 days are shown on Figure 10 (a and b), while the spectroscopy is shown on Figure 11 (a and $b$ ). The micrograph of the natural laterite shows a dull surface morphology that indicates an inter-grain porosity induced by microstructure alteration. This is similar to the observations reported in previous studies for which wax-curing periods were at 7 days and testing was carried out immediately after de-waxing [48-51].

The micrograph of the optimally treated laterite indicates that changes caused by cation exchange, flocculation-agglomeration, and carbonation caused the weakly bonded ions in the clay structure of the soil particles to be replaced by more active and higher valent cation i.e. $\mathrm{Ca}^{2+}$. The micrograph also showed the development of cementitious product of calcium silicates hydrates, calcium aluminate hydrates and calcium aluminosilicates hydrates which covered the soil grains and also filled the inner-aggregate pores. These compounds were responsible for the strength gain [52-54].

The elemental analyses (EDS) of the natural soil showed that the sample was composed of alumino silicates minerals $[51,52]$ with elements such as Al $(15.8 \%)$, Si $(15.8 \%)$, Fe (6.9 \%) with traces of $\mathrm{P}, \mathrm{Ti}$, $\mathrm{Cu}$ and $\mathrm{Zn}$ elements. The optimally treated specimen showed the presence of more elements in addition to those already in the natural specimen due to the presence of EFBA, some of which are Ca (3.2\%), Mg $(5.3 \%)$ and $\mathrm{K}(8.1 \%)$. Other additional trace elements were $\mathrm{Re}$ and $\mathrm{Pb}$. The presence of carbon in the EDS was due to the carbon tape at the background of the sample holder.

\subsubsection{Micrograph and spectroscopy of specimen wax-cured for 28 days and air-dried for 120 days}

The micrographs of the natural and treated samples wax cured for 28 days and air-dried for 120 days are shown on Figures 12 ( $a$ and $b$ ). The micrograph for the natural laterite showed changes in the microstructural particle orientation that appeared to 
be different from those of specimen wax-cured for 7 days. This could be attributed to the insignificant intersurface activity/reaction within the untreated sample during curing. However, the orientation changes indicate that flocculation of clay probably occurred through simple electrostatic attraction between positively charged particles edges and negative particle surface. Results observed were also similar to previous studies on samples wax-cured for 28 days and tested immediately after de-waxing [50,51].

The micrographs of the treated laterite showed whitish, floppy-like aggregated structure. It indicated that the clay particles and the flocs were grown within the pores. The stabilization reaction in the lateriteEFBA mixture might had taken place with complete flocculation and agglomeration, cation exchange and strength gain that contributed to the inner particle bonding of the mixture. Also, the curing period

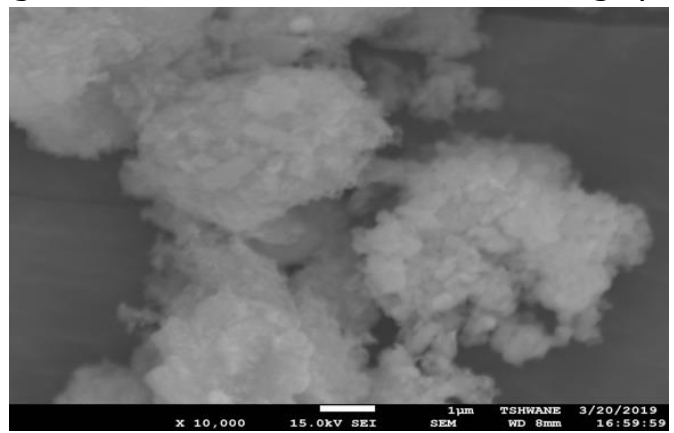

Figure 10a: Micrograph of natural soil after 127 days curing at $\times 10,000 \mathrm{Mg}$

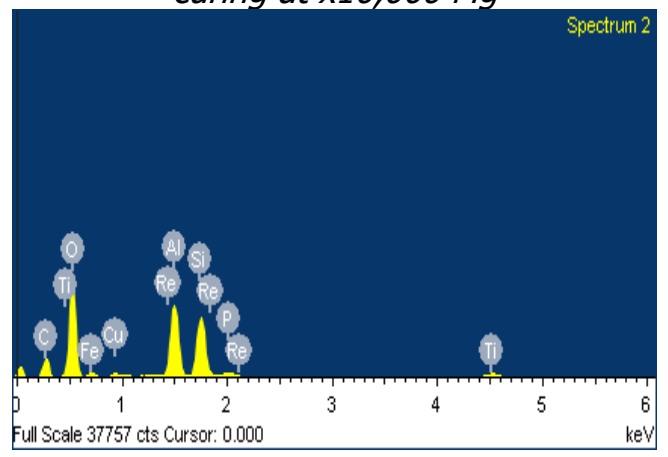

Figure 11a: EDS of natural soil after 127 days curing period

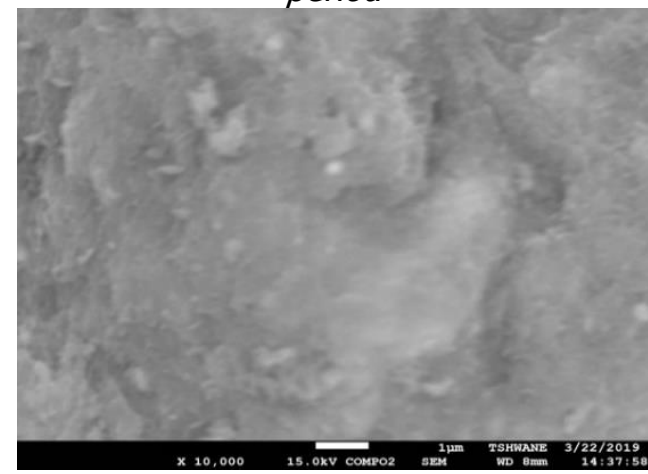

Figure 12a: Micrograph of natural soil after 148 days curing at $\times 10,000 \mathrm{Mg}$ enhanced the formation of cementitious compounds $[50,51]$.

The EDS elemental analysis of specimen wax cured for 28 days were similar to those wax-cured for 7 days however, the elements were all of higher quantities. It was observed from Figure $13 a$ and $b$ that the natural laterite soil with higher silicon content of $17.7 \%$ decreased to $10.9 \%$ in the laterite-8 \% EFBA mixture. This decrease in silicon content might be due to silicon in the natural laterite involved in hydration reaction with the calcium present in the EFBA. The spectrum of the silicon and aluminium detected from the EDS confirmed the dissolution of silica and alumina present in the laterite-EFBA mixture where cementitious compounds such as hydrated calcium silicates or hydrated calcium aluminates ( $\mathrm{C}-\mathrm{S}-\mathrm{H}$ and $\mathrm{C}-\mathrm{A}-\mathrm{H})$ were formed [50].

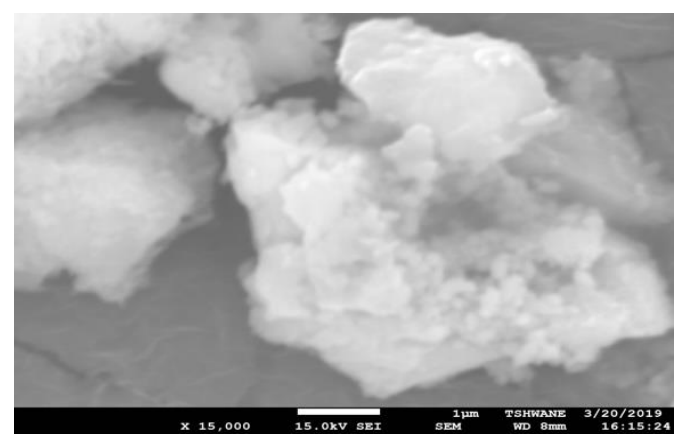

Figure 10b: Micrograph of $8 \%$ EFBA treated soil after 127 days curing at $X 10,000 \mathrm{Mg}$

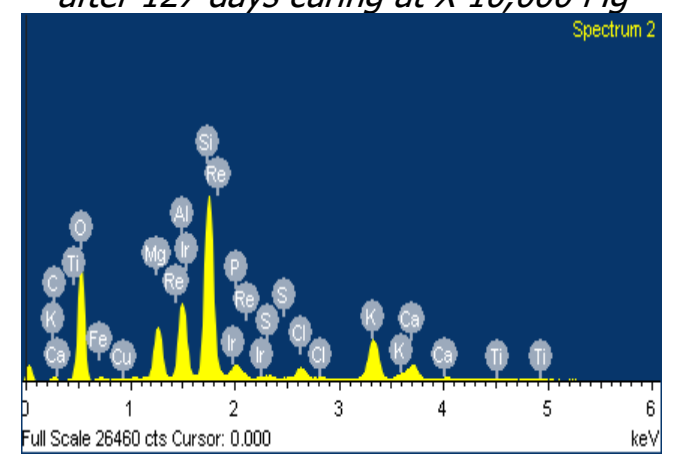

Figure 11b: EDS of $8 \%$ EFBA treated soil after 127 days curing period

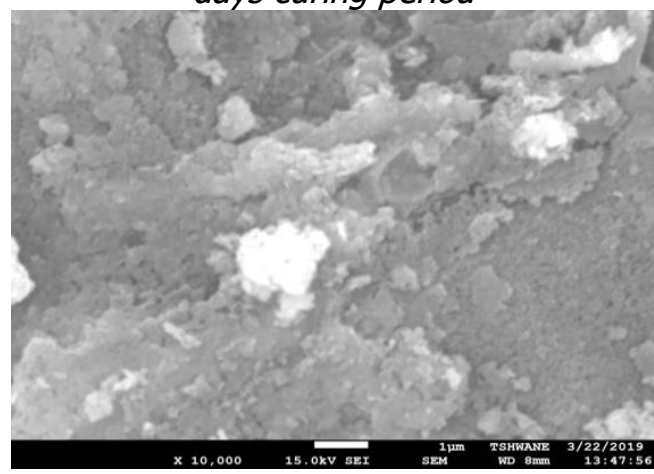

Figure 12b: Micrograph of 8\% EFBA after 148 days curing at $\times 10,000 \mathrm{Mg}$

Vol. 39, No. 3, July 2020 


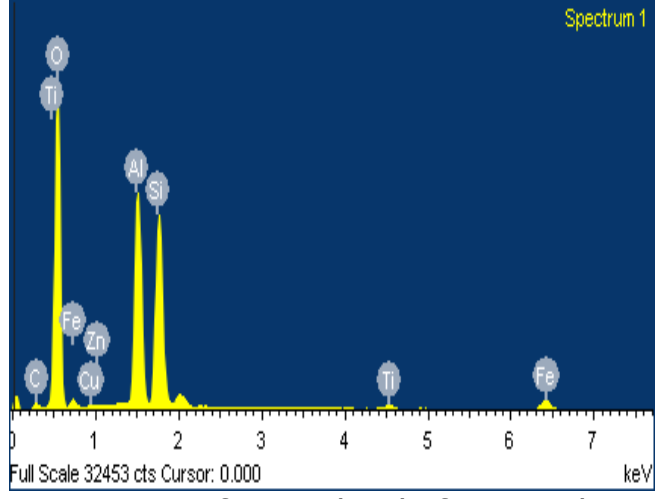

Figure 13a: EDS of natural soil after 148 days curing period

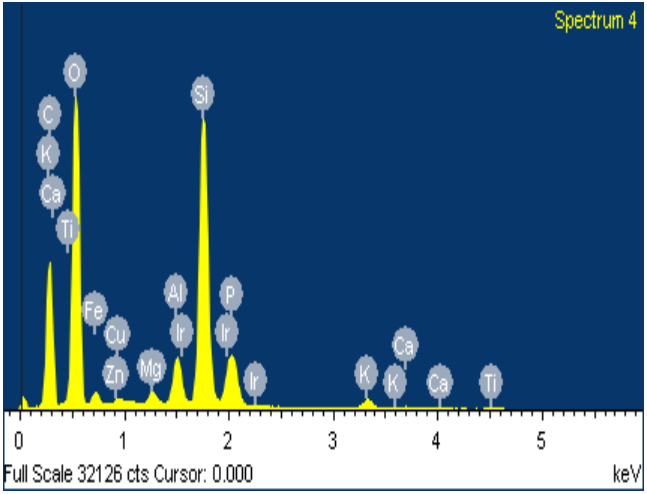

Figure 13b: EDS of $8 \%$ EFBA treated soil after 148 days curing period

\section{CONCLUSION}

Laterite soil classified as A-7-6 (15) and CL in the American Association of State Highway and Transportation Officials (AASHTO) and the Unified Soil Classification System, (USCS), respectively, was treated with up to $14 \%$ empty fruit bunch ash. Specimens were prepared using the BSL energy. Based on the results obtained the following conclusions can be made:

i. The Atterberg limits of the treated soil improved. LL and PI values decreased from 47.0 and 23.0 $\%$ for the natural laterite to values of 34.0 and $12.0 \%$, respectively, at $8 \%$ EFBA content.

ii. The strength characteristics of the soil improved. Peak UCS and CBR (soaked condition) values of $577 \mathrm{kN} / \mathrm{m}^{2}$ and $45 \%$, respectively, were recorded at $8 \%$ EFBA content.

iii. The resistance to loss in strength of the soil increased from $17.4 \%$ for the natural soil to a peak value of $19.3 \%$ at $8 \%$ EFBA content.

iv. There were no changes in the morphology of specimens that were de-waxed and air-dried for about 120 days before testing in comparison to samples tested immediately after de-waxing, hence samples produced possessed the required strength for fill material requirement in pavement construction.

\section{RECOMMENDATION}

From the results obtained in this study, it is recommended that laterite treated with $8 \%$ EFBA and compacted with BSL compactive effort can be used as fill material in the construction of lowvolume roads.

\section{REFERENCES}

[1] Oduola, R. Studies on a Cement Kiln Dust (CKD)Stabilized Low-Strength Soil for Road Pavement Construction in Eastern Nigeria. Green Streets and Highways Conference. Nov. 14-17, 2010, pp. 449-460.

[2] Osinubi, K. J. and Mustapha, A. M. (2008). Effects of Compactive Efforts on Cement Sugarcane Bagasse Ash-laterite Mixture Submitted to the Nigerian Society of Engineers Technical Transaction. (Accepted for Publication March 2008) Vol. 43, Number 2, pp. $33-46$.

[3] Osinubi, K. J. Treatment of laterite with anionic bitumen emulsion and cement: A comparative study. Ife Journal of Technology. Vol. 9, Number 1, 2000, pp. 139-145.

[4] Oke, S. A., Amadi, A. N., Abalaka, A. E., Nwosu, J. E. and Ajibade, S. A. Index and Compaction Properties of Laterite Deposits for Road Construction in Minna Area, Nigeria. Nigerian Journal of Construction Technology and Management. Vol. 10, Numbers 1 and 2, 2009, pp. 28-35.

[5] Alayaki, F. M. Water Absorption Properties of Laterite Soil in Road Pavement: A Case Study IfeIlesha Highway, South Western Nigeria. International Journal of Emerging Technology and Advanced Engineering. Volume 2, Number 11, 2012, pp. 51-57.

[6] Amadi, A.N., Akande W. G., Okunlola I. A., Jimoh M.O., Francis Deborah G. Assessment of the Geotechnical Properties of Lateritic Soils in Minna, North Central Nigeria for Road design and Construction. American Journal of Mining and Metallurgy. Vol. 3 Number 1, 2015, pp 15-20.

[7] Oluremi, J.R., S.I. Adedokun, and O.M. Osuolale. "Effect of Coconut Husk Ash on the Geotechnical Properties of Poor Lateritic Soil". Pacific Journal of Science and Technology. Vol. 13, Number 2, 2012, pp. 499-507. 
[8] Patel, M. A. and Patel, H. S. A Review on Effects of Stabilizing Agents for Stabilization of Weak Soil, Civil and Environmental Research. Vol. 2, Number 6, 2012, pp.1-7.

[9] Alhassan, M. Potentials of rice husk ash for soil stabilization. Assumption University Journal of Technology. Vol. 11, Number 4, 2008, pp 246 250.

[10] Edeh, J., Tyav, S., and Osinubi, K. Cassava Peel Ash Stabilized Lateritic Soil as Highway Pavement Material. Pavement Materials, Geo-Shanghai Conference, May 26-28, 2014, pp. 375-382.

[11] Bello, A.A., Ige, J.A., Ayodele, H. Stabilization of Lateritc Soil with Cassava Peel Ash. British Journal of Applied Science and Technology. Vol. 7 Number 6, 2015, 642-650.

[12] Amu, O.O., Ogunniyi, S.A. and Oladeji, O.O. Geotechnical properties of lateritic soil stabilized with sugarcane straw ash. American Journal of Scientific and Industrial Research.Vol.2 Number 2, 2011. 323-331.

[13] Ogunribido, T.H.T. Potentials of Sugarcane Straw Ash for Lateritic Soil Stabilization in Road Construction. International Journal of Science \& Emerging Technologies. Vol. 3, Number 5, 2012, pp. 102-106.

[14] Abdullah, N. and Sulaiman, F. The Oil Palm Wastes in Malaysia, Biomass Now - Sustainable Growth and Use, Miodrag Darko Matovic IntechOpen, 2013, pp 75-100.

[15] Nigerian Oil Palm Sector Report: Full Steam Ahead. AFRINVEST. 2019.

[16] X-raying the Nigerian Oil Palm Sector. World Bank and PricewaterhouseCoopers Report 2019.

[17] Manual for the Provision of Low Volume Roads TRL 2016.

[18] Design manual for low volume roads, Part B (Design standards for low volume roads) 2011.

[19] BS 1377. Methods of Testing Soil for Civil Engineering Purposes. British Standards Institute, London, 1990.

[20] BS 1924. Methods of Tests for Stabilized Soils. British Standards Institute, London, 1990.

[21] Federal Ministry of Works and Housings. Roads and Bridges. In: Nigerian General Specification, Abuja, Nigeria, 13-25, 1997.

[22] American Society for Testing Materials (ASTM C 618-78). Standard specification for fly ash and raw or calcined natural pozzolan for use as a mineral admixture in Portland cement concrete.

[23] Osinubi, K. J. Lime Modification of Black Cotton Soil. Spectrum Journal, Vol. 2, Numbers 1 and 2, 1995, pp. 112-122.
[24] Osinubi, K. J. Evaluation of admixture stabilization of Nigerian black cotton soil. Nigerian Society of Engineers Technical Transactions. Vol. 34, Number 3, 1999, pp. 88-96.

[25] Moses, G. and Afolayan, J. O. "Compacted Foundry Sand Treated with Cement Kiln Dust as Hydraulic Material. Electronic Journal of Geotechnical Engineering. Vol.16, 2011, pp. 337355.

[26] Osinubi, K. J. Yohanna, P., and Eberemu, A. O. "Cement modification of tropical black clay using iron ore tailings as admixture." Transportation Geotechnics, Elsevier, Vol. 5, 2015, pp. 35 - 49.

[27] Ogunribido, T.H.T. Potentials of Sugar Cane Straw Ash for Lateritic Soil Stabilization in Road Construction. International. Journal of Science. \& Emerging Technologies. Vol. 3, Number 5, 2012, pp. 102-106.

[28] Yinusa, A. Jimoh, Apampa, Ahmed O. An Evaluation of the Influence of Corn Cob Ash on the Strength Parameters of Lateritic Soils. Civil and Environmental Research, Vol. 6, Number 5, 2014, pp. 1-10.

[29] O'Flaherty, C. A. Highway Engineering. Vol. 2, Edward Arnold, London, 1988.

[30] Ola, S. A. Laboratory testing and geotechnical characterization of black cotton soil and expansive shales in Nigeria. Proceedings of the 9th Regional Conference for Africa on Soil Mechanics and Foundation Engineering, Balkema, Rotterdam, 1991, pp. 991- 995.

[31] Iorliam, A. Y., Agbede, I. O. and Joel M. Effect of cement kiln dust on some geotechnical properties of black cotton soil. Electronic Journal of Geotechnical Engineering 17(H), 2012, pp. 967977.

[32] Salahudeen, A. B. Eberemu, A. O. Osinubi, K. J. Assessment of cement kiln dust-treated expansive soil for the construction of flexible pavements. Geotechnical and Geological Engineering, 2014, pp. 923-931.

[33] Sani, J. E., Afolayan, J. O., Chukwujama, I. A. and Yohanna, P. Effects of wood saw dust ash admixed with treated sisal fibre on the geotechnical properties of lateritic soil. Leonardo Electronic Journal of Practices and Technologies. ISSN 1583-1078, Issue 31, 2017, pp. 59-76.

[34] Sani, J. E., Yohanna, P. and Chukwujama, I. A. Effect of rice husk ash admixed with treated sisal fibre on properties of lateritic soil as a road construction material. Vol. 13, Number 1, 2018, pp. 11-18.

[35] Ola, S. A. Stabilization of Nigerian lateritic soils with cement, bitumen, and lime, Proceedings of the 6th Regional Conference for Africa on Soil Mechanics and Foundation Engineering, 1975.

Vol. 39, No. 3, July 2020 
[36] Gidigasu, M.D. Laterite Soil Engineering: Pedogeneses and Engineering Principles. Development in Geotechnical Engineering Amsterdam, Elsevier Scientific Publishing Company, 1976.

[37] Musa, A. Potential of Rice Husk Ash for soil stabilization. AUJ.T. Vol. 11, Number 4, 2008, pp. 246-250.

[38] Osinubi, K. J., Eberemu, A. O., Yohanna, P., and Etim, R. K. Reliability estimate of the compaction characteristics of iron ore tailings treated tropical black clay as road pavement sub-base material. Geo-Chicago 2016 - Sustanability, Energy and the Geoenvironment, U. S. A. Edited by Krishna R. Reddy,Nazli Yesiller,Dimitrios Zekkos, Arvin Farid and Anirban De. American Society of Civil Engineers Geotechnical Special Publication, GSP No 271, 2016, pp. 855-864.

[39] Osinubi, K.J., Oyelakin, M. A. and Eberemu, A.O. Improvement of Black Cotton Soil with Ordinary Portland Cement - Locust Bean Waste Ash Blend. EJGE, Bund F. Vol.16, 2011, pp. 619-627.

[40] Moses, G. K. and Saminu, A. Cement Klin Dust Stabilization of Compacted Black Cotton Soil. IRJI Journal of Research in Engineering. Vol. 17, 2012, pp. 826-834.

[41] Ingles, O. G. and Metcalf, J. B. Soil Stabilization Principles and Practice, Butterworths, Sydney, 1972.

[42] Ola, S. A. The Geotechnical Properties of Black Cotton Soils of North Eastern Nigeria. In S. A. Ola (ed) Tropical Soil of Nigeria in Engineering Practice. Balkama, Rotterdam, 1983, pp. 160-178.

[43] Negi, A. S., Faizan, M., Siddharth, D. P., Singh, R. Soil Stabilization using Lime. International Journal of Innovative Research in Science, Engineering and Technology. Vol 2, Number 2, 2013, pp. 448453.

[44] Ola, S. A. Need for Estimated Cement Requirement for Stabilizing Lateritic soil. Journal of Transportation Division. ASCE, Vol.17 Number 8, 1974, pp. 379-388.

[45] Osinubi, K.J., Ijimdiya, T. S. and Nmadu, I. 'Lime Stabilization of Black Cotton Soil using Bagasse Ash as Admixture.' Advanced Materials Research, Vols. 62 - 64, 2009, pp. 3 - 10. In: Advances in Materials Systems Technologies II. Online http://www.scientific.net TransTech Publications, Switzerland.
[46] Mannir, I, Yohanna, P and Osinubi, K. J. Evaluation of Compacted Black Cotton Soil Sawdust Ash Mixtures as Road Construction Material. Nigerian Journal of Materials Science and Engineering. Vol. 7, Number 2, 2016, pp.65 72.

[47] Osinubi, K. J. Influence of Compactive Efforts and Compaction Delays on Lime Treated Soils. Journal of Transportation Engineering, American Society of Civil Engineers. Vol. 124, Number 2, 1998, pp. 149-155.

[48] Zhang, G., Germaine, J. T., Whittle, A. J. Drying Induced Alterations to the Microstructure of a Tropical Soil. Proceedings of International Symposium on Advanced Experimental Unsaturated Soil Mechanics, Trento, Italy. In: Tarantino A. Romero E, Cui YJ (eds) Advanced Experimental Un-saturated Soil Mechanics. Taylor \& Francis Group, London, pp. 2005, 443-449, 2729.

[49] Romero, E. and Simms, P. H. Investigation in Unsaturated Soils. A Review with Special Attention to Contribution of Mecury Intrusion Porosimetry and Environmental Scanning Electron Microscopy. Journal of Geotechnical and Geological Engineering. Vol. 8, 2008, pp. 1-23.

[50] Saleh, S. Micro level analysis of weak soils stabilized with locust bean waste ash (LBWA). International Journal of Civil Engineering and Construction Science, Vol. 2, Number 2, 2015, pp. 9-15.

[51] Etim, R. K., Eberemu, A. O. and Osinubi, K. J. Stabilization of black cotton soil with lime and iron ore tailings admixture. Transportation Geotechnics, Vol. 10, 2017, pp. 85-95.

[52] Lambe, T. W., and Martin, R. T. Composition of Engineering Properties of Soil II, Proceedings, Highway Research Board, Vol. 33, 1954.

[53] Mallela, J., Quintux, H. V. and Smith, K. Consideration of Lime-stabilized Layers in mechanistic- Empirical Pavement Design. The National Lime Association, 2004.

[54] Deneele, D., Cuisinier, O., Hallaire, V. and Masrouri, F. Microstructural Evolution and Physico -chemical Behaviour of Compacted Clayey Soil Submitted to an Alkaline Plume. Journal of Rock Mechanics and Geotechnical Engineering. Vol. 2, Number 2, 2010, pp. 169-177. 